\title{
The nutritive value of silages \\ Digestion of nitrogenous constituents in sheep receiving diets of grass silage and grass silage and barley.
}

\author{
By P. C. THOMAS, D. G. CHAMBERLAIN, N. C. KELLY \\ AND M. K. WAIT \\ The Hanmah Research Institute, Ayr KA6 $5 \mathrm{HL}$ \\ (Received I6 July 1979 - Accepted 4 October 1979)
}

\begin{abstract}
1. Two experiments were conducted to study the digestion of nitrogenous constituents in the rumen, small intestine and caecum and colon of sheep given diets of grass silage or grass silage and barley. Three silages were used. One was made from first-harvest grass in the spring and the others from regrowth grass cut in either early autumn or late autumn. All were of perennial ryegrass (Lolium pereme) and were preserved with formic acid.

2. Expt 1 involved a comparison between the spring silage given alone (644 g dry matter (DM)/d) and the spring silage supplemented with bariey $(\mathrm{I} 5 \mathrm{Ig} \mathrm{DM} / \mathrm{d})$. The intakes $(\mathrm{g} / \mathrm{d})$ of total nitrogen for the silage diet and for the supplemented diet were 14.89 and 17.36 . Corresponding values $(\mathrm{g} / \mathrm{d})$ for $\mathrm{N}$ passage were 15.55 and $18.53(P<0.01)$ at the duodenum, 6.01 and 7.09 at the ileum and 5.06 and 5.52 in the faeces. The barley supplement had no significant $(P<0.05)$ effect on rumen ammonia- $\mathrm{N}$ concentration.

3. Expt 2 involved a comparison between the two autumn-cut silages each offered at a level of feeding of approximately $700 \mathrm{~g} \mathrm{DM} / \mathrm{d}$. The intakes $(\mathrm{g} / \mathrm{d})$ of total $\mathrm{N}$ for the early-cut silage and for the late-cut silage were 21.67 and 15.62 respectively. Corresponding values $(\mathrm{g} / \mathrm{d})$ for $N$ passage were 17.10 and 16.96 at the duodenum, 6.65 and 6.80 at the ileum and 4.5 and 5.22 in the faeces. The concentration of $\mathrm{NH}_{3}-\mathrm{N}$ in the rumen was significantly $(P<0.001)$ higher with the early-cut silage than with the late-cut silage.

4. In both experiments the rates of bacterial crude protein $(N \times 6.25)$ synthesis in the rumen, estimated using $x, \epsilon$-diaminopimelic acid as a marker, were low, 142 and $\mathrm{I} 61 \mathrm{~g}$ crude protein $/ \mathrm{kg}$ organic matter apparently digested in the rumen for the spring silage and the spring silage and barley diets respectively, and 68 and $103 \mathrm{~g}$ crude protein $/ \mathrm{kg}$ organic matter apparently digested in the rumen for the early-cut autumn silage and the late-cut autumn silage respectively. For all diets there was a relatively low contribution of bacterial crude protein to the duodenal passage of crude protein and the amounts of individual amino acids ingested in the diets had a marked influence on the amino acids passing to the duodenum and as a consequence on the mixture of amino acids taken up from the small intestine.
\end{abstract}

5. The results are discussed in relation to the nutritive value of silage $\mathrm{N}$ for ruminants.

Ensilage of grass leads to extensive hydrolysis of the plant proteins and to a partial degradation of the amino acids formed (see Oshima \& McDonald, 1978). In sheep and cows given highly-digestible perennial ryegrass (Lolium perenne) silages prepared using formic acid as an additive a large proportion of the apparently-digested nitrogen is excreted in the urine and although the proportion is reduced when the silage is supplemented with barley (Kelly \& Thomas, 1978; McDonald \& Thomas, 1978) dairy-cow-feeding experiments have indicated that the nutritive value of dietary crude protein in silage-barley diets is low (Castle, 1975).

Thomas et al. (1979) studied the sites of digestion of organic matter, gross energy and carbohydrates in sheep receiving three formic-acid-preserved silages. One silage was made from first-harvest grass in the spring and offered either alone or with a barley supplement, the others were from regrowth grass cut in either early autumn or late autumn. In the present paper results pertaining to the digestion of nitrogenous constituents obtained in the experiments of Thomas et al. (1979) are reported, and they are discussed in relation to the nutritive value of silage $\mathrm{N}$ for ruminant animals. 
Table I. The concentration of total nitrogen, non-protein- $N$ and ammonia- $N$ in the diets and the dietary contents of digestible organic matter and rumen-digestible organic matter

Total N (g/kg DM)

Non-protein- $\mathrm{N}(\mathrm{g} / \mathrm{kg}$ total $\mathrm{N})$

$\mathrm{NH}_{3}-\mathrm{N}(\mathrm{g} / \mathrm{kg}$ total $\mathrm{N})$

Digestible organic matter $(\mathrm{g} / \mathrm{kg} \mathrm{DM})$

Rumen-digestible organic matter

$(\mathrm{g} / \mathrm{kg} \mathrm{DM}) \ddagger$

\begin{tabular}{|c|c|c|c|}
\hline \multicolumn{2}{|c|}{ Expt I } & \multicolumn{2}{|c|}{ Expt 2} \\
\hline Spring silage & $\begin{array}{l}\text { Spring silage } \\
\text { and barley* }\end{array}$ & $\begin{array}{c}\text { Early-cut } \\
\text { autumn silage }\end{array}$ & $\begin{array}{l}\text { Late-cut } \\
\text { autumn silage }\end{array}$ \\
\hline 23.4 & $22 \cdot 0$ & $31 \cdot 9$ & $22 \cdot I$ \\
\hline 644 & $555^{\dagger}$ & 395 & 538 \\
\hline 139 & 120 & 44 & 89 \\
\hline 643 & 682 & 744 & 678 \\
\hline $42 I$ & 427 & 537 & 506 \\
\hline
\end{tabular}

DM, dry matter.

* For proportions, see p. 470.

+ Barley $N$ assumed to be protein.

$¥$ Digestible organic matter and dietary organic matter apparently digested in the rumen, from Thomas et al. (1979).

\section{MATERIALS AND METHODS}

Details of the experimental designs, animals, collection procedures and statistical analyses were given by Thomas et al. (1979). Two experiments were conducted. Expt I involved a comparison between a spring silage $(644 \mathrm{~g} \mathrm{DM} / \mathrm{d})$ and the same silage supplemented with rolled barley ( $644 \mathrm{~g}$ silage $\mathrm{DM} / \mathrm{d}$ plus I5I g barley DM/d). Expt 2 involved a comparison between two silages (each offered at approximately $700 \mathrm{~g} \mathrm{DM} / \mathrm{d}$ ) prepared from the same regrowth grass sward cut at either an early or late stage of maturity in the autumn. Methods of chemical analysis were as described by Kelly \& Thomas (1978) and Thomas et al. (1979). Samples for amino acid analysis were prepared by hydrolysis with $6 \mathrm{~m}$-hydrochloric acid in sealed tubes at $105^{\circ}$ for $24 \mathrm{~h}$. Samples for cystine analysis were prepared by oxidation with $0.86 \mathrm{M}$-performic acid before hydrolysis. Individual amino acids were separated and determined using an automatic amino acid analyser (LKB Instruments, Croydon, Surrey) following the procedure of Moore et al. (1958).

\section{RESULTS}

The composition of the diets

The total $\mathrm{N}$ contents of the diets and the concentrations of non-protein- $\mathrm{N}$ and ammonia- $\mathrm{N}$ in the total nitrogen are given in Table $\mathrm{I}$ together with the dietary contents of digestible organic matter and rumen-digestible organic matter derived from the results of Thomas et al. (1979). In both Expt $\mathrm{I}$ and Expt 2 a large proportion of the total $\mathrm{N}$ in each diet was in non-protein form, although the concentrations of $\mathrm{NH}_{3}-\mathrm{N}$ in the diets was low. In Expt I, for the spring silage and barley diet the $\mathrm{N}$ content was lower and the digestible organic matter content was higher than for the diet of silage alone; the values for total $\mathrm{N}$ : digestible organic matter for the diets were 0.0322 and 0.0364 respectively. In Expt 2 the early-cut silage had a higher total $\mathrm{N}$ content and digestible organic matter content than the late-cut silage; the values for total $N$ :digestible organic matter for the diets were 0.0429 and 0.0326 respectively.

Table 2 shows the results for the amino acid composition of the diets. In addition to the amino acids shown the silages contained $\alpha, \epsilon$-diaminopimelic acid in low concentrations, less than $100 \mathrm{mg} / \mathrm{kg}$ DM. In Expt I both diets had a similar total amino acid (TAA)-N content and amino acid composition. 
Table 2. The amino acid composition ( $\mathrm{g}$ amino acid $/ \mathrm{kg}$ determined amino acids) of the diets and the dietary content of determined total amino acid nitrogen $(T A A-N)$

\begin{tabular}{|c|c|c|c|c|}
\hline \multirow[b]{2}{*}{ Amino acid } & \multicolumn{2}{|c|}{ Expt I } & \multicolumn{2}{|c|}{ Expt 2} \\
\hline & $\begin{array}{c}\text { Spring } \\
\text { silage }\end{array}$ & $\begin{array}{l}\text { Spring silage } \\
\text { and barley* }\end{array}$ & $\begin{array}{l}\text { Early-cut } \\
\text { autumn silage }\end{array}$ & $\begin{array}{l}\text { Late-cut } \\
\text { autumn silage }\end{array}$ \\
\hline Aspartic acid & 109 & 102 & I I4 & 130 \\
\hline $\begin{array}{l}\text { Threonine } \\
\text { Serine }\end{array}$ & $\begin{array}{l}57 \\
63\end{array}$ & $\begin{array}{l}54 \\
62\end{array}$ & $\begin{array}{l}59 \\
6 I\end{array}$ & $\begin{array}{l}63 \\
69\end{array}$ \\
\hline Glutamic acid & 160 & I 81 & 149 & 136 \\
\hline Proline & 97 & IOI & 67 & 69 \\
\hline Glycine & 63 & 60 & 68 & 68 \\
\hline Alanine & 99 & 88 & 88 & 84 \\
\hline Cystine & I I & 15 & 12 & 10 \\
\hline Valine & 70 & 65 & 6I & 63 \\
\hline Methionine & 16 & 17 & II & I5 \\
\hline Isoleucine & 50 & 45 & 42 & 42 \\
\hline Leucine & 67 & 64 & 92 & 85 \\
\hline Tyrosine & 16 & 17 & 25 & 28 \\
\hline Phenylalanine & 36 & 37 & 53 & 49 \\
\hline Histidine & 16 & 18 & 17 & 22 \\
\hline Lysine & 36 & 37 & 34 & 30 \\
\hline Arginine & 34 & 33 & 46 & 39 \\
\hline TAA-N (g/kg DM) & $10 \cdot 3$ & 10.5 & $17 \cdot 5$ & 9.5 \\
\hline
\end{tabular}

Table 3. The mean quantities $(\mathrm{g} / 24 \mathrm{~h})$ of total nitrogen in the food and faeces and of total $N$ and non-ammonia-N (NAN) entering and leaving the small intestine of sheep given diets of spring silage and spring silage and barley (Expt $\mathrm{I}$ ) and early-cut autumn silage and late-cut autumn silage (Expt 2) and values for the porportion of apparently-digested $N$ ' disappearing' before the small intestine, in the small intestine and in the caecum and colon

(Mean values with their standard errors; no. of animals/treatment in parentheses)

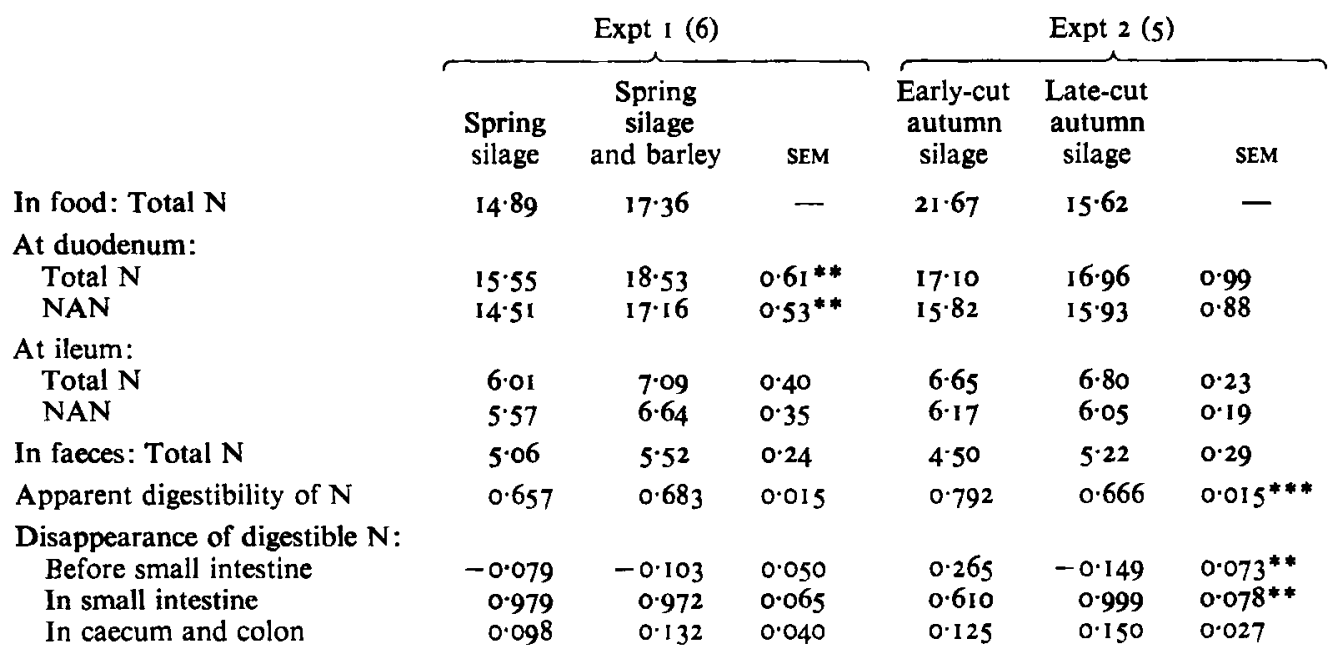

Statistical significance of difference between treatments: $* * P<0.01,{ }^{* *} P<0.001$. 
Table 4. The amino acid composition ( $\mathrm{g} / \mathrm{kg}$ determined amino acids) of duodenal digesta of sheep given diets of spring silage and spring silage and barley (Expt 1 ) and early-cut autumn silage and late-cut autumn silage (Expt 2)

(Mean values with their standard errors; no. of animals/treatment in parentheses)

\begin{tabular}{|c|c|c|c|c|c|c|}
\hline \multirow[b]{2}{*}{ Amino acids } & \multicolumn{3}{|c|}{ Expt I (6) } & \multicolumn{3}{|c|}{ Expt 2 (5) } \\
\hline & $\begin{array}{l}\text { Spring } \\
\text { silage }\end{array}$ & $\begin{array}{l}\text { Spring silage } \\
\text { and barley }\end{array}$ & SEM & $\begin{array}{c}\text { Early-cut } \\
\text { autumn } \\
\text { silage }\end{array}$ & $\begin{array}{c}\text { Late-cut } \\
\text { autumn } \\
\text { silage }\end{array}$ & SEM \\
\hline Aspartic acid & 146 & 133 & $3 \cdot 6^{*}$ & 105 & 128 & $3 \cdot 8^{* *}$ \\
\hline Threonine & 69 & 75 & 3.9 & 53 & 65 & $I \cdot 9^{* *}$ \\
\hline Serine & 57 & 52 & $0.9^{* * *}$ & 49 & 56 & $1 \cdot 9^{*}$ \\
\hline Glutamic acid & 138 & 139 & $3 \cdot 8$ & 97 & 126 & $7 \cdot 3^{*}$ \\
\hline Proline & 47 & 43 & $3 \cdot 0 t$ & 77 & 38 & $2 \cdot 7^{* *}$ \\
\hline Glycine & 67 & 70 & $1 \cdot 8$ & 52 & 76 & $5 \cdot 8^{*}$ \\
\hline Alanine & 80 & 69 & $4 \cdot 1$ & 72 & 72 & $5 \cdot 6$ \\
\hline Cystine & 13 & 16 & $1 \cdot 1$ & 14 & 18 & $1 \cdot 3^{*}$ \\
\hline Valine & 66 & 63 & $\mathrm{I} \cdot 2$ & 64 & 69 & $4: 5$ \\
\hline Methionine & I 6 & 17 & 0.9 & 20 & 15 & $2 \cdot 1$ \\
\hline$\alpha, \epsilon$-diaminopimelic acid & 4 & 5 & 0.4 & 2 & 3 & $0.2^{* * *}$ \\
\hline Isoleucine & 45 & 47 & $1 \cdot 3$ & 59 & 48 & $2 \cdot 4^{*}$ \\
\hline Leucine & 59 & 66 & $3 \cdot 1$ & 104 & 93 & $6 \cdot 7$ \\
\hline Tyrosine & 35 & 42 & $3 \cdot 0$ & 36 & 39 & $4 \cdot 3$ \\
\hline Phenylalanine & 46 & 50 & $2 \cdot 6$ & 66 & 42 & $4 \cdot 2^{* *}$ \\
\hline Histidine & 17 & 19 & $1 \cdot 1$ & 6 & 9 & $1 \cdot 2$ \\
\hline Lysine & 63 & 60 & $2 \cdot 0$ & 76 & 73 & $4 \cdot 6$ \\
\hline Arginine & 32 & 37 & $1 \cdot 9$ & 50 & 32 & $3.6^{* *}$ \\
\hline
\end{tabular}

Statistical significance of difference between treatments: ${ }^{*} P<0.05,{ }^{* *} P<0.01,{ }^{* * *} P<0.001$. $\dagger$ SEM for spring silage, $n 4$; for spring silage and barley multiply SEM by I.07.

\section{Digestion of nitrogenous constituents in the rumen and intestines}

Rumen $\mathrm{NH}_{3}-\mathrm{N}$ concentrations. With each of the four diets used there were pronounced postfeeding 'peaks' in the $\mathrm{NH}_{3}-\mathrm{N}$ content of the rumen fluid; concentrations were maximum in samples taken $\mathrm{I} h$ or $2 \mathrm{~h}$ after feeding, In Expt I supplementation of the silage diet with barley had no significant $(P<0.05)$ effect on $\mathrm{NH}_{3}-\mathrm{N}$ concentration at any of five sampling times over the period $0-6 \mathrm{~h}$ after feeding; mean 'daily' values $(\mathrm{mg} / \mathrm{l})$ were 202 for the silage diet and 198 for the silage and barley diet (SEM 17.9;P>0.05). In contrast, in Expt 2 there were significant $(P<0.05)$ differences with diet in rumen $\mathrm{NH}_{3}-\mathrm{N}$ concentration at each sampling; mean 'daily' values were (mg/l) 242 (SEM 14.7) for the early-cut autumn silage and I68 (SEM 4.0 ) for the late-cut autumn silage $(P<0.001$ ).

Sites of digestion of $N$. The spring silage diet in Expt I provided $14.89 \mathrm{~g}$ total $\mathrm{N} / \mathrm{d}$ whilst for the spring silage and barley diet the value was $\mathrm{I} 7.36 \mathrm{~g}$ total $\mathrm{N} / \mathrm{d}$ (Table 3 ). With both diets there was a net gain in total $\mathrm{N}$ from the food to the duodenum and the duodenal passage of total $\mathrm{N}$ for the barley-supplemented diets was significantly $(P<0.0 \mathrm{I})$ greater than for the silage diet. This difference closely paralleled the difference between the diets in the intakes of rumen-digestible organic matter which were 273 and $339 \mathrm{~g} / \mathrm{d}$ for the spring silage diet and the spring silage and barley diet respectively. The passage of total $N$ to the ileum and faeces for each of the diets reflected the passage at the duodenum; the mean digestibilities of duodenal $\mathrm{N}$ before the ileum were 0.611 and 0.617 (SEM $0.02 ; P>0.05$ ), and before the faeces were 0.674 and 0.701 (SEM $0.008 ; P<0.05$ ) for the spring silage and spring silage and barley diets respectively. There were significant differences between diets 

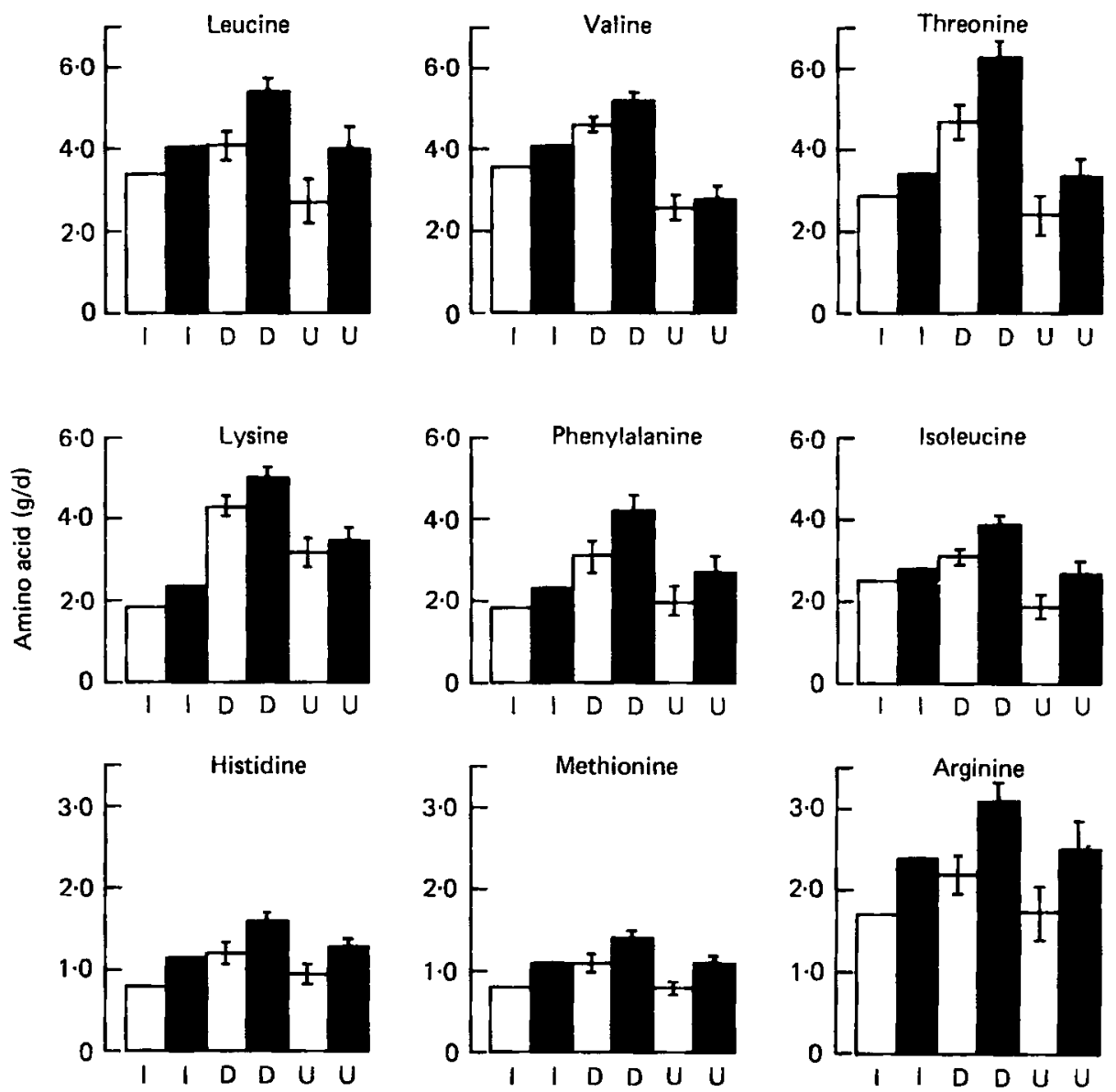

Fig. I. Expt 1. The amounts of individual 'essential' amino acids in the food $(I)$, passing to the duodenum $(D)$ and taken up between the proximal duodenum and terminal ileum $(U)$ in sheep given diets of $(\square)$ spring silage and of ( $\boldsymbol{D})$ spring silage and barley. Values are means with their standard errors represented by vertical bars, for six animals.

in the passage of $\mathrm{NH}_{3}-\mathrm{N}$ to the duodenum or ileum and the results for $\mathrm{NAN}$ closely followed those for total-nitrogen.

In Expt 2, the intake of total $\mathrm{N}$ was greater with the early-cut silage than with the late-cut silage (Table 3) but the intakes of rumen-digestible organic matter, 366 and $360 \mathrm{~g} / \mathrm{d}$, were similar for both diets. For the early-cut silage there was a loss of $\mathrm{N}$ before the duodenum whilst for the late-cut silage there was a gain in $\mathrm{N}$. There were no significant $(P<0.05)$ differences between silages in the passage of total $\mathrm{N}$ at the duodenum, at the ileum or in the faeces. The mean apparent digestibilities of duodenal $\mathrm{N}$ between the duodenum and the ileum were $0.60 \mathrm{I}$ and $0.60 \mathrm{I}$ (SEM 0.03 ) and between the duodenum and the faeces were 0.729 and 0.703 (SEM 0.02) for the early-cut silage and the late-cut silage respectively. There was a large and significant $(P<0.001)$ difference between the silages in the apparent digestibility of dietary $\mathrm{N}$ which was due entirely to events within the rumen.

Amino acid composition of duodenal digesta. Despite the differences between diets in the duodenal flow of $\mathrm{N}$ in Expt $\mathrm{I}$, differences between diets in the amino acid composition of the duodenal digesta (Table 4$)$ were small and significant only for aspartic acid $(P<0.05)$ and serine $(P<0.00 \mathrm{I})$. In contrast in Expt 2, where duodenal flows of $\mathrm{N}$ were similar for 

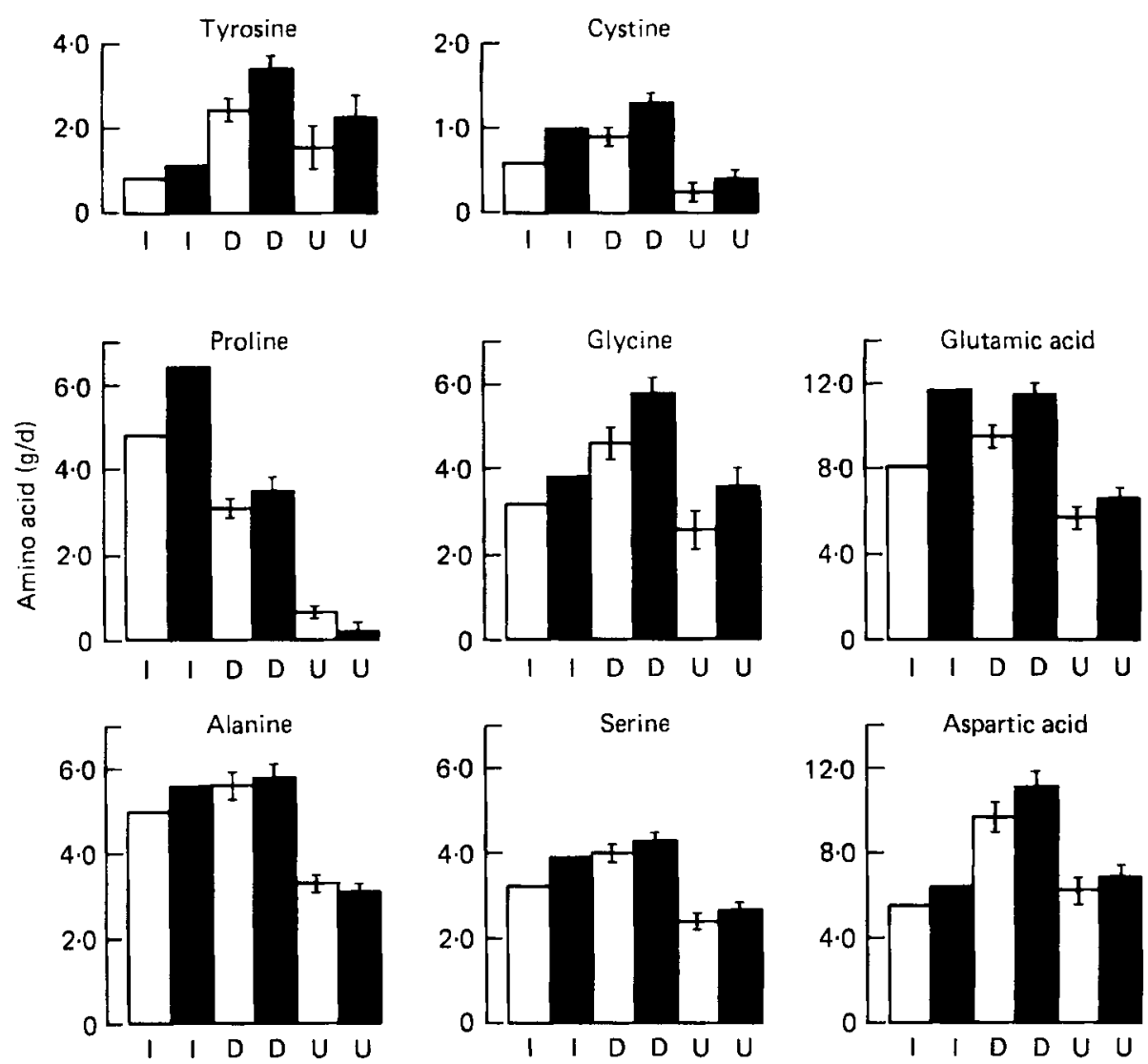

Fig. 2. Expt $\mathrm{I}$. The amounts of individual 'non-essential' amino acids in the food $(I)$, passing to the duodenum $(D)$ and taken up between the proximal duodenum and terminal ileum $(U)$ in sheep given diets of $(\square)$ spring silage and of $(\square)$ spring silage and barley. Values are means with their standard errors represented by vertical bars, for six animals.

both diets, there were significant differences between diets in the duodenal concentration of aspartic acid, threonine, serine, glutamic acid, proline, glycine, cystine, $\alpha, \epsilon$-diamino pimelic acid, isoleucine, phenylalanine and arginine (Table 4).

Amino acid intake, duodenal passage and uptake from the small intestine. Figs. I and 2 summarize the results from Expt I for the dietary intake, passage to the duodenum and net uptake between the duodenum and terminal ileum of individual amino acids. Excepting proline and cystine, the duodenal passage of each amino acid was greater than the amount consumed in the diet and for lysine, phenylalanine, histidine, arginine, tyrosine and aspartic acid the amount taken up from the small intestine was also greater than the intake. Supplementation of the silage diet with barley increased the intake of each amino acid, and there were corresponding and consistent increases for each amino acid in the amount passing to the duodenum and in the amount taken up between the duodenum and ileum. In most instances the differences between diets in the duodenal passage of amino acids were statistically significant $(P<0.05)$ but the standard errors of estimates of amino acid uptake were relatively large and differences between diets in uptake generally did not reach significance at $P<0.05$.

The results for Expt 2 (Figs. 3 and 4) showed more variable relationships between the 

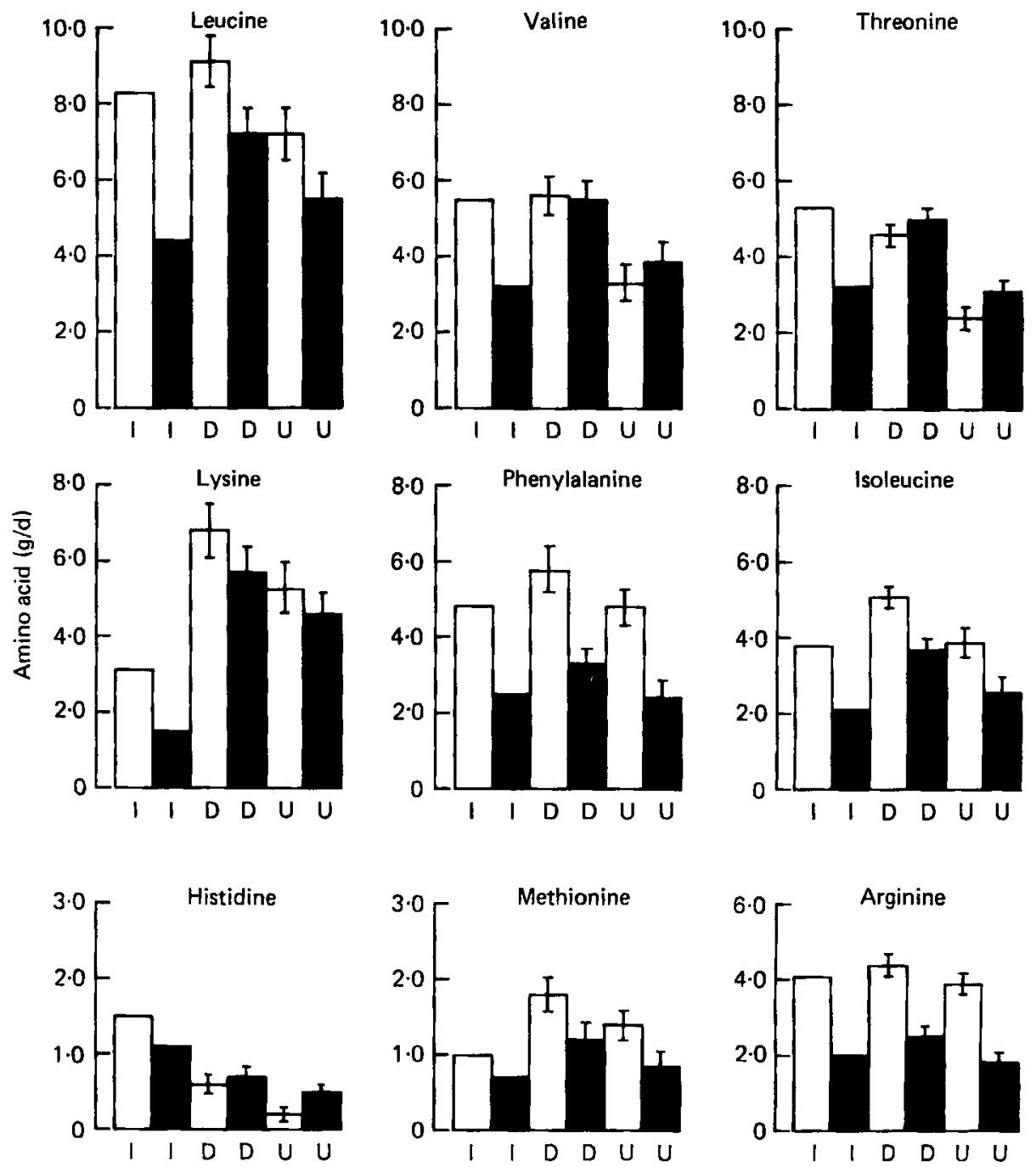

Fig. 3. Expt 2. The amounts of individual 'essential' amino acids in the food $(I)$, passing to the duodenum $(D)$ and taken up between the proximal duodenum and terminal ileum $(U)$ in sheep given diets of $(\square)$ early-cut autumn silage and of $(\square)$ late-cut autumn silage. Values are means with their standard errors represented by vertical bars, for five animals.

duodenal passage of amino acids and the dietary intake of amino acids than were observed in Expt I. For some acids there was a net gain from the food to the duodenum with one silage and a net loss from the food to the duodenum with the other, for example see valine, threonine, proline, glycine, glutamic acid, alanine, serine and aspartic acid (Figs 3 and 4). There were significant differences between diets in the duodenal passage of proline $(P<$ $0.001)$, glycine and isoleucine $(P<0.05)$ and phenylalanine and arginine $(P<0.01)$. Differences between diets in intestinal uptake were significant for isoleucine $(P<0.05)$, phenylalanine $(P<0.01)$, glycine $(P<0.05)$ and arginine $(P<0.01)$.

Bacterial crude protein synthesis in the rumen. The passage of bacterial $\mathrm{N}$ to the duodenum was calculated from the passage of $\alpha, \epsilon$-diaminopimelic acid (Hogan \& Weston, 1970) on the basis that bacteria contain $45 \mathrm{mg} \alpha, \epsilon$-diaminopimelic acid/g total $\mathrm{N}$ (Chamberlain \& 

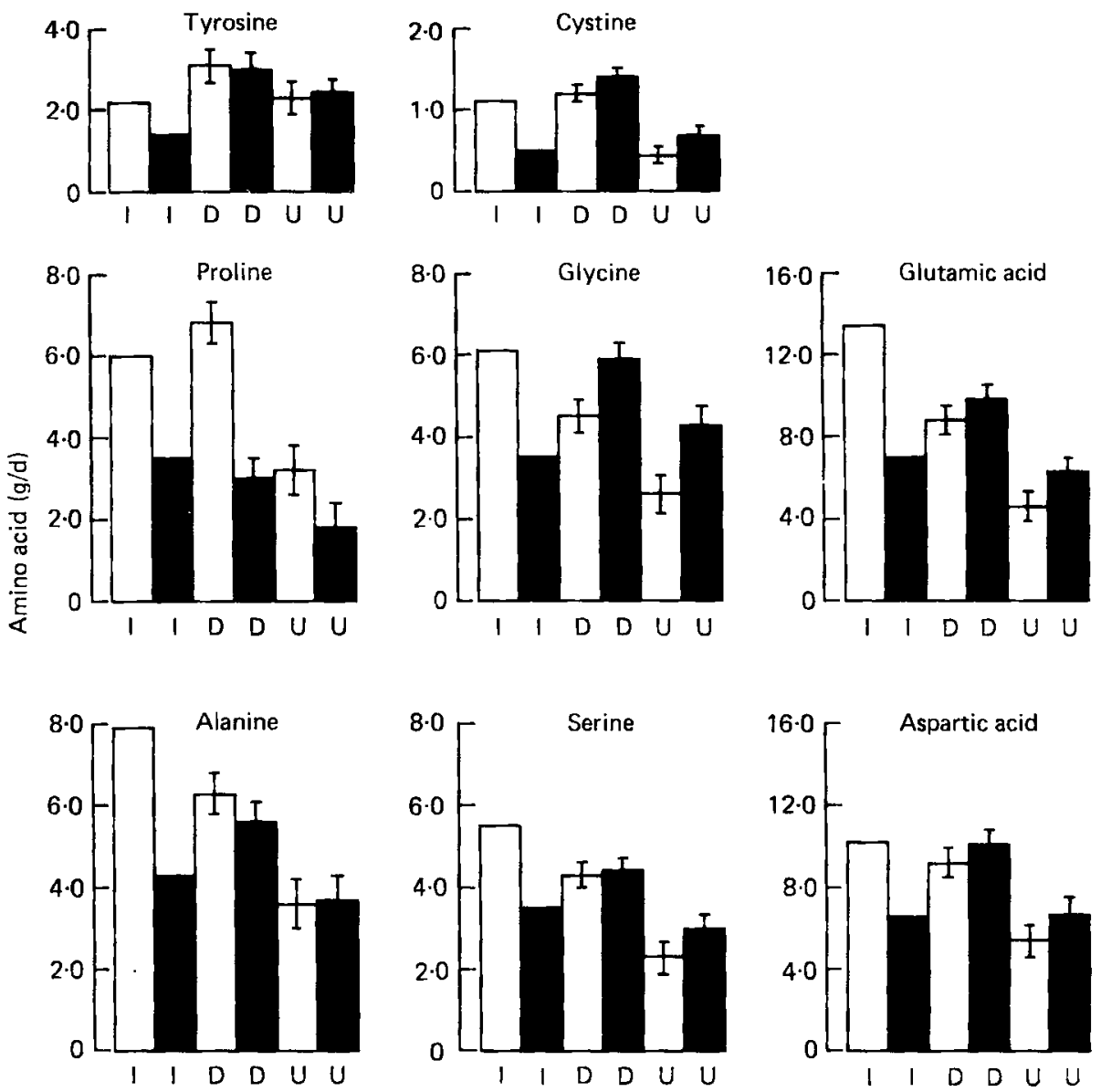

Fig. 4. Expt 2. The amounts of individual 'non-essential' amino acids in the food $(I)$, passing to the duodenum $(D)$ and taken up between the proximal duodenum and terminal ileum $(U)$ in sheep given diets of $(\square)$ early-cut autumn silage and of $(\boldsymbol{D})$ late-cut autumn silage. Values are means with their standard errors represented by vertical bars, for five animals.

Thomas, 1979). Since dead bacterial cells are degraded in the rumen (Nolan \& Leng, 1972) and $\alpha, \epsilon$-diaminopimelic acid is metabolized by rumen micro-organisms (Lane \& Ling, 1979) it was assumed that the $\alpha, \epsilon$-diaminopimelic acid ingested in the silages was degraded in the rumen, and that the bacterial $\mathrm{N}$ passing to the duodenum represented bacterial crude protein synthesized in the rumen.

In Expt $I$ the two diets had a similar rumen-digestible organic matter content (Table I) so that the intake of rumen-digestible organic matter varied with the DM intake; there was a significant $(P<0.00 \mathrm{I})$ difference between diets in the duodenal passage of bacterial $\mathrm{N}$ (Table 5). Rates of bacterial crude protein synthesis per $\mathrm{kg}$ organic matter digested in the rumen did not, however, differ significantly between diets (Table 5).

In Expt 2 dietary intakes of rumen-digestible organic matter were similar for both diets but there were significant $(P<0.01$ and $P<0.05)$ differences between diets in the duodenal passage of bacterial nitrogen (Table 5 ) and in the rate of bacterial crude protein synthesis (Table 5). 
Table 5. The mean quantities of bacterial nitrogen passing to the duodenum and the rates of bacterial crude protein $(N \times 6.25)$ synthesis in the rumen in sheep given diets of spring silage and spring silage and barley (Expt $\mathrm{I}$ ) and early-cut autumn silage and late-cut autumn silage (Expt 2)

(Mean values with their standard errors; no. of animals/treatment in parentheses)

$\begin{array}{llc} & & \begin{array}{c}\text { Bacterial cr } \\ \text { protein synt } \\ \text { (g crude pro } \\ \text { kg organic }\end{array} \\ & \begin{array}{c}\text { Bacterial N } \\ (\mathrm{g} / 24 \mathrm{~h})\end{array} & \begin{array}{c}\text { apparently di } \\ \text { in the rume }\end{array} \\ \text { Expt I (6): } & & \\ \text { Spring silage } & 5.91 & 142 \\ \text { Spring silage and barley } \dagger & 8.55 & 161 \\ \text { SEM } & 0.55^{* * *} & 15 \\ \text { Expt 2 (5): } & & \\ \text { Early-cut autumn silage } & 3.78 & 68 \\ \text { Late-cut autumn silage } & 5.92 & 103 \\ \text { SEM } & 0.31^{* *} & 7.5^{*}\end{array}$

Statistical significance of difference between treatments: ${ }^{*} P<0.05,{ }^{* *} P<0.01,{ }^{* * *} P<0.001$. † For proportions, see p. 470 .

Table 6. The relationships between the passage of amino acids to the duodenum $(g / d)$ and the intake of amino acids in the diet $(\mathrm{g} / \mathrm{d})$ and between the uptake of amino acids in the small intestine $(\mathrm{g} / \mathrm{d})$ and the passage of amino acids to the duodenum $(\mathrm{g} / \mathrm{d})$ in sheep receiving diets of silage or silage and barley

(The relationships are derived from the mean values observed with the four diets used in Expt I and Expt 2)

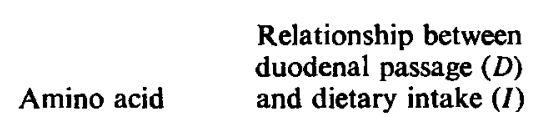

Aspartic acid

Threonine

Serine

Glutamic acid

Proline

Glycine

Alanine

Cystine

Valine

Methionine

Isoleucine

Leucine

Tyrosine

Phenylalanine

Histidine

Lysine

Arginine

\section{duodenal passage $(D)$}

$D=$ II $52-0.204 I$

$D=5.95-0.209 I$

$D=3 \cdot 88+0.090 I$

$D=9.95-0.005 I$

$D=0.42+0.707 I$

$D=6.33-0.271 I$

$D=4 \cdot 74+0 \cdot 190 I$

$D=1 \cdot 10+0.097 I$

$D=4 \cdot 38+0.203 I$

$D=0.13+I .339 I$

$D=I \cdot 04+I \cdot 037 I$

$D=2.03+0.879 I$

$D=2.53+0.320 I$

$D=I .55+0.889 I$

$D=1.97-0.842 I$

$D=3.39+0.930 I$

$D=0.78+0.878 I$

Relationship between uptake in the small

Correlation coefficient

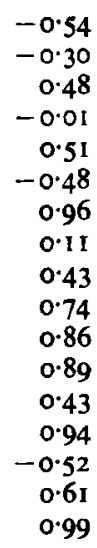

intestine $(U)$ and duodenal Correlation passage $(D)$

$U=-1.22+0.751 D$
$U=-0.02+0.549 D$
$U=-0.85+0.814 D$
$U=-0.59+0.646 D$
$U=-0.99+0.592 D$
$U=-2.31+1 \cdot 060 D$
$U=1 \cdot 55+0.320 D$
$U=-0.37+0.690 D$
$U=-1.64+0.915 D$
$U=-0.21+0.912 D$
$U=-1 \cdot 16+0.994 D$
$U=-1.00+0.908 D$
$U=-0.08+0.743 D$
$U=-1 \cdot 10+0.994 D$
$U=-0.22+0.952 D$
$U=-0.99+0.938 D$
$U=-0.68+1.050 D$ coefficient
0.89
0.87
0.51
0.86
0.80
0.95
0.33
0.91
0.76
$1 \cdot 00$
$I \cdot \infty$
I. 00
0.81
0.97
0.98
0.98
I. 00 


\section{DISCUSSION}

The results of the experiments described here highlight several features of the digestion of the nitrogenous constituents in formic-acid silages which may have significance in determining the nutritive value of the silage $N$. In the first instance, it is clear from the results of Expt 1 and Expt 2 that the duodenal passage of total $N$ and NAN does not directly reflect the $\mathrm{N}$ intake and varies with the quantity of organic matter digested in the rumen. Relationships between duodenal $\mathrm{N}$ passage, dietary $\mathrm{N}$ intake and rumen-digested organic matter, similar to those observed here, have been widely reported for dried forage diets. In a summary of results of experiments with Australian forages, Hogan (1975) described the relationship by the equation $Y=0.33+0.0288 X$, where $Y$ is the total $\mathrm{N}$ reaching the intestine ( $\mathrm{g} / \mathrm{g}$ total $\mathrm{N}$ intake) and $X$ is the intake of digestible organic matter $(\mathrm{g} / \mathrm{g}$ total $\mathrm{N}$ intake). For the diets used in the present experiments this equation provides estimates of duodenal total $\mathrm{N}$ passage $3-28 \%$ higher than those actually observed, Similar over estimates of $3^{-11} \%$ are obtained for three diets containing red-clover silage reported by Thomas et al. (1976), and of $20 \%$ for the control grass silage used by Beever et al. (1977).

In the present experiments the rates of bacterial crude protein synthesis in the rumen were low (Table 5) especially with the early-cut and late-cut autumn silages in Expt 2; rates of bacterial protein synthesis for dried-forage diets are typically $19-23 \mathrm{~g}$ crude protein $/ \mathrm{kg}$ organic matter apparently digested in the rumen (Hogan \& Weston, 1970). In both Expt I and Expt 2 there was a much lower proportion of bacterial crude protein in the protein passing to the duodenum than is normally observed with dried-forage diets. A similar low proportion of bacterial crude protein in the duodenal crude protein was reported by Thomas et al. (1976) for sheep given diets containing red-clover silage. With silage diets much of the crude protein at the duodenum must be of dietary, protozoal or endogenous origin. In sheep endogenous secretions in the abomasum could contribute approximately $2 \mathrm{~g} \mathrm{~N} / \mathrm{d}$ to the N passing to the duodenum (Harrop, I974). Thus of the NAN passing to the duodenum in Expt $\mathrm{I}$ and Expt 2 dietary plus protozoal $\mathrm{N}$ was approximately $6.6,6.6,10.0$ and $8.0 \mathrm{~g} / \mathrm{d}$ for the spring silage, spring silage and barley, early-cut autumn silage and late-cut autumn silage diets respectively. The amount of protozoal $\mathrm{N}$ was probably small, possibly $1-2 \mathrm{~g} / \mathrm{d}$ (Weller \& Pilgrim, 1974) and this suggests that a substantial part of the $N$ at the duodenum was in undigested dietary crude protein. The intakes $(\mathrm{g} / \mathrm{d})$ of true protein- $\mathrm{N}$ in the spring silage and spring silage and barley diets in Expt 1 were 5.3 and $7 \cdot 7(5.3$ from silage) whilst in Expt 2 the corresponding values were 13.2 for the early-cut autumn silage and $7 \cdot 2$ for the late-cut autumn silage. The evidence suggests that the ruminal degradability of the true protein in the silage was low.

There is support for this suggestion elsewhere in the results; there were consistent relationships between the dietary intake and duodenal passage of certain of the amino acids (Table 6). Moreover the uptake of individual amino acids in the small intestine was generally closely related to the entry of the amino acid into the duodenum (Table 6) so that for certain amino acids the intake in the diet had an important influence on the uptake from the small intestine.

As a consequence of the low rate of bacterial protein synthesis and of the low degradability of silage true protein in the rumen, the mixture of amino acids passing to the duodenum and absorbed in the intestine was low in methionine and lysine. In sheep given hay, and hay and cereal diets the duodenal amino acid mixture contained $30-40 \mathrm{~g}$ methionine $/ \mathrm{kg}$ total amino acids and 75-95 $\mathrm{g}$ lysine/ $\mathrm{kg}$ total amino acids (Chamberlain \& Thomas, 979 ); corresponding values in the present experiments were $15^{-20} \mathrm{~g}$ methionine $/ \mathrm{kg}$ total amino acids and $60-76 \mathrm{~g}$ lysine $/ \mathrm{kg}$ total amino acids. Intravenous infusion experiments have shown that methionine is limiting for tissue synthesis in sheep given a diet of formic-acid silage 
(Kelly \& Thomas, 1975) and a limited supply of methionine and lysine to the tissues may be an important factor contributing to the low nutritive value of silage $\mathrm{N}$ for dairy cows (see Castle, 1975).

In conclusion, the present results indicate that with formic acid silages of the type used here, the duodenal passage of total $N$ is slightly lower than that which would be predicted for a dried-forage diet of corresponding $\mathrm{N}$ and digestible organic matter content. Furthermore, the silage diets appear to have a characteristically-low ruminal synthesis of bacterial crude protein and high duodenal passage of silage true protein which has an important influence on the composition of the amino acid mixture passing to and taken up from the small intestine. The reasons for the resistance of the silage true protein to microbial attack in the rumen and for the low ruminal rates of bacterial protein synthesis require further study; the importance of the dietary supply of essential nutrients such as sulphur to the rumen bacteria remains to be investigated.

The authors are grateful to Mrs A. Maxwell, Mrs A. McLaughlin and Miss A. G. Wilson and her staff for skilled technical assistance, to $\mathrm{MrS}$. Robertson for care of the experimental animals and to $\mathrm{MrJ}$. N. Watson for making available the grasses and the silage. N.C.K. is grateful to the Meat and Livestock Commission for a postgraduate award.

\section{REFERENCES}

Beever, D. E., Thomson, D. J., Cammell, S. B. \& Harrison, D. G. (1977). J. agric. Sci, Camb. 88, 6I. Castle, M. E. (1975). Agric. Prog. 50, 53.

Chamberlain, D. G. \& Thomas, P. C. (1979). J. Sci. Fd Agric. 30, 677.

Harrop, C. J. F. (1974). J. agric. Sci., Camb. 83, 249.

Hogan, J. P. (1975). J. Dairy Sci. 58, i 164.

Hogan, J. P. \& Weston, R. H. (1970). In Physiology of Digestion and Metabolism in the Ruminant, p. 474

[A. T. Phillipson, editor]. Newcastle-upon-Tyne: Oriel Press.

Kelly, N. C. \& Thomas P. C. (1978). Br. J. Nutr. 40, 205.

Lane, H. A. \& Ling, J. R. (1979). Proc. Nutr. Soc. 38, 80 A.

McDonald, L. \& Thomas, P. C. (1978). Proc. 1oth int. Dairy Congr., p. 63.

Moore, S., Spackman, D. M. \& Stein, W. M. (1958). Analyt. Chem. 30, 1185.

Nolan, J. V. \& Leng, R. A. (1972.) Br. J. Nutr. 27, 177.

Oshima, M. \& McDonald P. (1978). J. Sci. Fd Agric. 29, 497.

Thomas, P. C., Chamberlain, D. G. \& Alwash, A. H. (1976). J. Br. Grassld Soc. 3r, 123.

Thomas, P. C., Kelly, N. C., Chamberlain, D. G. \& Wait, M. K. (1979). Br. J. Nutr. 43, 481.

Weller, R. A. \& Pilgrim, A. F. (1974). Br. J. Nutr. 32, 34 I. 